\title{
PERLINDUNGAN HUKUM BAGI KONSUMEN KESEHATAN DALAM HAL TERJADI MALAPRAKTIK
}

\author{
Istiana Heriani \\ Fakultas Hukum Universitas Islam Kalimantan MAB \\ Jalan Adhyaksa No.2 Kayutangi Banjarmasin Kalimantan Selatan \\ E-mail: iheriani2579@gmail.com
}

\begin{abstract}
Health is a thing that must be maintained by every human being, because health is an investment to build human resources that are socially and economically productive. Law no.36 2009 years Article 1 Paragraph (1) mentions health is a prosperous state of the body, soul and social that enable every person to live socially and economically productive, then in Article 4 stated: everyone has equal rights in obtaining degreesoptimal health.the occurrence of malpractice in medical acts committed either intentionally or by gross negligence which endangers the patient and resulted in the harm suffered by the patient / consumer health. the existence of Law Number 8 Year 1999 on Consumer Protection in this case patient / consumer health has not fully guaranteed its right.
\end{abstract}

Keywords: Legal Protection, Health, Malpractice.

\begin{abstract}
Abstrak
Kesehatan merupakan hal yang harus dijaga oleh setiap manusia, karena kesehatan merupakan investasi untuk membangun sumber daya manusia yang produktif secara sosial dan ekonomi. Undang-undang No. 36 Tahun 2009 tentang Kesehatan, Pasal 1 Ayat (1) menyebutkan kesehatan adalah keadaan sejahtera dari badan, jiwa dan sosial yang memungkinkan setiap orang hidup produktif secara sosial dan ekonomi, selanjutnya dalam Pasal 4 dinyatakan: setiap orang mempunyai hak yang sama dalam memperoleh derajat kesehatan yang optimal. Terjadinya malapraktik dalam tindakan medis yang dilakukan baik dengan sengaja maupun karena kelalaian berat yang membahayakan pasien dan mengakibatkan kerugian yang diderita oleh pasien/ konsumen kesehatan. Adanya Undangundang Nomor 8 Tahun 1999 tentang Perlindungan Konsumen dalam hal ini pasien/konsumen kesehatan belum sepenuhnya dapat terjamin haknya.
\end{abstract}

Kata Kunci: Perlindungan Hukum, Kesehatan, Malpraktik.

\section{PENDAHULUAN}

Kesehatan merupakan salah satu hal yang mutlak dibutuhkan manusia. Ironisnya, dunia medis adalah salah satu dunia yang sedikit sekali diketahui orang awam. Kelompok professional medis dan keahliannya seakan menjadi pengetahuan yang ekslusif bagi mereka saja. Kondisi ini terjadi, bahkan saat pasien berhadapan dengan keadaan yang menyangkut keselamatan dirinya.

Padahal pasien berhak mengetahui segala hal yang berkaitan dengan perlakuan medis maupun obat yang 
dikonsumsinya. Ini menyangkut konsekuensi biaya, efek samping, dan efek jangka panjang konsumsi tersebut.

Pada awal berdirinya Yayasan Pemberdayaan Konsumen Kesehatan Indonesia (YPKKI) pada tahun 1998, hanya sedikit pengaduan tentang dugaan malapraktik. Namun saat ini, semakin marak pasien atau keluarganya yang mengadukan ketidakpuasan atas pelayanan tersebut. Bahkan, Puskesmas hingga Rumah Sakit besar dengan gedung dan fasilitas modern pun tidak luput dari pengaduan dugaan malapraktik yang dilakukan oleh tenaga kesehatannya. Namun demikian, pengaduan melalui YPKKI tersebut hanyalah sebagian kecil dari berbagai kasus yang terungkap. Kasus dugaan malapraktik dalam kedokteran sering terjadi. Banyak kasus dugaan malapraktik yang dilakukan oleh dokter diberitakan di berbagai media cetak maupun media elektronik, dari banyaknya dugaan kasus malapraktik hanya beberapa saja yang sampai di pengadilan. Dari resume kasus pengaduan ke IDI Wilayah DKI Jakarta selama Desember 2005-Maret 2015, tercatat 72 kategori pengaduan. Yang terbanyak adalah miskomunikasi (40 kasus) yang setelah diperiksa MKEK ada yang terbukti melanggar etik, tetapi banyak pula yang tidak melanggar etik.
Banyaknya kasus malapraktik yang terjadi juga terkait erat dengan hak bagi anggota masyarakat khususnya pasien yang berperan sebagai konsumen kesehatan. Salah satu hak yang dimiliki oleh anggota masyarakat ialah memperoleh perlindungan dalam kedudukannya sebagai konsumen. Hal ini sangat wajar mengingat kedudukan tersebut terjadi akibat dari adanya interaksi pihak lain, yang antara lain di antara para pihak secara prinsip mempunyai kepentingan berbeda. Dalam hal ini, pihak konsumen berkepentingan untuk memperoleh manfaat yang sebaik mungkin atas barang dan jasa yang dikonsumsinya, terkait dalam hal ini adalah jasa di bidang medis, sedangkan produsen barang maupun pemberi jasa atau pelaku usaha berkepentingan untuk memperoleh keuntungan dari produk atau jasa yang dijualnya. Berdasarkan perbedaan dasar kepentingan antara konsumen dan pelaku usaha maka kemungkinan timbulnya persoalan akibat adanya benturan kepentingan menjadi terbuka.

Hak konsumen secara internasional telah diakui melalui The International Organization of Consumer's Union. Dalam upaya pemberdayaan konsumen Indonesia, pada tanggal 20 April 1999 telah diundangkan Undang- 
Undang Nomor 8 Tahun 1999 tentang Perlindungan Konsumen. Undang-undang ini mulai berlaku setelah satu tahun sejak diundangkannya (Pasal 65 UndangUndang Nomor 8 Tahun 1999). Dengan demikian, Undang-undang ini sudah mulai berlaku sejak Tanggal 20 April 2000.

Dalam malapraktik medik, selain aspek hukum perdata, juga melekat didalamnya aspek hukum pidana. Meskipun dalam hal perlindungan konsumen cenderung berkaitan dengan segi perdata. Untuk dapat dikatakan telah terjadi malapraktik medik menurut hukum perdata adalah telah terjadi penyimpangan dari standar profesi kedokteran. Namun sayangnya, hingga saat ini Peraturan Pemerintah (PP) tentang Standar Profesi yang diamanatkan Undang-Undang Nomor 35 Tahun 2009 tentang Kesehatan belum ada.

Dokter dan pasien adalah dua subjek hukum yang terkait dalam Hukum Kedokteran. Keduanya membentuk baik hubungan medik maupun hubungan hukum. Hubungan medik dan hubungan hukum antara dokter dan pasien adalah hubungan yang objeknya pemeliharaan kesehatan pada umumnya dan pelayanan kesehatan pada khususnya. Dalam melaksanakan hubungan antara dokter dan pasien, pelaksanaan hubungan antara keduanya selalu diatur dengan peraturan-peraturan tertentu agar terjadi keharmonisan dalam pelaaksanaannya.

Untuk mengetahui bagaimana perlindungan hukum bagi konsumen kesehatan dalam hal terjadi malapraktik perlu dirumuskan permasalahan yang akan dikaji sebagai berikut :

1. Bagaimana perlindungan bagi konsumen kesehatan dalam hal telah terjad i malapraktik?

2. Apa yang menjadi kendala pemenuhan hak atas ganti kerugian bagi konsumen kesehatan dalam hal terjadi malapraktik medik?

\section{PEMBAHASAN}

\section{Kriteria dan Unsur Malapraktik}

Malapraktik merupakan suatu tindakan medis yang dilakukan tidak memenuhi standar medis yang telah ditentukan maupun standar operasional prosedur, baik dengan sengaja maupun karena kelalaian berat yang membahayakan pasien dan mengakibatkan kerugian yang diderita oleh pasien.

Kata malapraktik berasal dari kata "mala", berarti buruk dan "praktik", pelaksanaan profesi. Pengertian hukum malapraktik banyak diambil dari literatur luar negeri, antara lain World Medical Association (WMA,1992): 
"medical malpractice involves the physician's failure to conform to the standard of care for treatment of the patient's condition, or lack of skill, or negligence in providing care to the patient, which is the direct cause of an injury to the patient".

Untuk menembus kesulitan dalam menilai dan membuktikan apakah suatu perbuatan itu termasuk kategori malapraktik atau tidak, biasanya dipakai 4(empat) kriteria, antara lain: ${ }^{1}$

1. Apakah perawatan yang diberikan oleh dokter cukup layak (aduty of due care) Dalam hal ini standar perawatan yang diberikan oleh pelaksana kesehatan dinilai apakah sesuai dengan apa yang diharapkan

2. Apakah terdapat pelanggaran kewajiban (the breach of the duty);

3. Apakah itu benar-benar merupakan penyebab cidera (causation). Adanya ganti rugi (damages).

\section{Perlindungan Hukum Terhadap}

\section{Kepada Konsumen.}

Perlindungan Konsumen menurut Pasal 1 angka 1 Undang-Undang Nomor 8 Tahun 1999 tentang Perlindungan Konsumen adalah segala upaya yang menjamin adanya kepastian hukum untuk memberi perlindungan konsumen dan pelaku usaha (pengusaha) pada dasarnya

\footnotetext{
${ }^{1}$ Maryati, Ninik, Malpraktek Kedokteran, Bina Aksara, Jakarta, 1988, hlm. 54
}

adalah hubungan hukum yang menimbulkan hak dan kewajiban secara timbal balik antara kedua belah pihak.

Berdasarkan Pasal 3 Undang-

Undang Nomor 8 Tahun 1999, Perlindungan Konsumen, bertujuan untuk:

1. Meningkatkan kesadaran, kemampuan, dan kemandirian konsumen untuk melindungi diri;

2. Mengangkat harkat dan martabat konsumen dengan cara menghindarkannya dari akses negatif pamakaian barang dan/atau jasa;

3. Meningkatkan pemberdayaan konsumen dalam memilih, menentukan dan menuntut hakhaknya sebagai konsumen;

4. Menciptakan sistem perlindungan konsumen yang mengandung unsur kepastian hukum dan keterbukaan informasi serta akses untuk mandapatkan informasi;

5. Menumbuhkan kesadaran pelaku usaha mengenai pentingnya perlindungan konsumen sehingga tumbuh sikap yang jujur dan bertanggung jawab dalam berusaha;

6. Meningkatkan kualitas barang dan/atau jasa yang menjamin kelangsungan usaha produksi barang dan/atau jasa, kesehatan, 
kenyamanan, keamanan, dan

keselamatan konsumen.

\section{Hak Untuk Mendapatkan Ganti Rugi}

Merupakan hak konsumen untuk memperoleh ganti rugi terhadap kerugian yang diderita atau gangguan kesehatannya. Undang-Undang Nomor 8 Tahun 1999 tentang Perlindungan Konsumen, Pasal 4 huruf h, menyebutkannya dengan hak untuk mendapatkan kompensasi, ganti rugi dan/atau penggantian, apabila barang dan/atau jasa yang diterima tidak sesuai dengan perjanjian atau tidak sebagaimana mestinya.

Kerugian yang diderita seseorang secara garis besar dapat dibagi atas dua bagian, yaitu kerugian yang menimpa harta benda seseorang. Sedangkan kerugian harta benda sendiri dapat berupa kerugian nyata yang dialami serta kehilangan keuntungan yang diharapkan. Kedua bentuk kerugian tersebut dapat dinilai dengan uang (harta kekayaan).

Penentuan besarnya ganti kerugian yang harus dibayar, pada dasarnya harus berpegang pada asas bahwa ganti kerugian yang harus dibayar sedapat mungkin membuat pihak yang rugi dikembalikan pada kedudukan semula seperti sebelum terjadinya kerugian atau dengan kata lain ganti kerugian menempatkan sejauh mungkin orang yang dirugikan dalam kedudukan yang seandainya perjanjian dilaksanakan secara baik atau tidak terjadi perbuatan melanggar hukum. Oleh karenanya, ganti kerugian harus diberikan sesuai dengan kerugian yang sesungguhnya. Hak ini sangat terkait dengan penggunaan barang atau jasa yang telah merugikan konsumen baik yang berupa kerugian materi, maupun kerugian yang menyangkut diri (sakit, cacat, bahkan kematian) konsumen.

Di dalam Undang-Undang Nomor 8 Tahun 1999 tentang Perlindungan Konsumen, konsumen dapat secara langsung meminta ganti kerugian kepada pelaku usaha, hal ini tertuang dalam Pasal 19 ayat (1) Undang-Undang Nomor 8 Tahun 1999 yang menyatakan bahwa pelaku usaha bertanggung jawab memberi ganti rugi ${ }^{2}$ atas kerusakan, pencemaran dan/atau kerugian konsumen akibat mengkonsumsi barang dan atau jasa yang dihasilkan atau diperdagangkan.

Ketentuan dalam Pasal 19 ayat (2) belum memberikan perlindungan kepada konsumen yang mengalami kerugian

2 Adapun ganti rugi sebagaimana yang dimaksud dalam Pasal 19 ayat (2) UndangUndang Nomor 8 Tahun 1999 tersebut dapat berupa: a. Pengembalian uang; b. Penggantian barang dan atau jasa yang sejenis atau setara nilainya; c. Perawatan kesehatan; d. Pemberian santunan yang sesuai dengan ketentuan peraturan perundang-undanganyang berlaku. 
secara maksimal, terutama dalam hal konsumen menderita suatu penyakit. Melalui pasal tersebut, konsumen hanya memperoleh salah satu bentuk ganti kerugian yaitu ganti kerugian atas harga barang atau hanya berupa perawatan kesehatan, padahal konsumen telah menderita kerugian bukan hanya kerugian atas harga barang tetapi juga kerugian yang ditimbulkan dari biaya perawatan kesehatan.

Menurut KUH Perdata bagi pihak yang dirugikan dalam suatu hubungan hukum dengan pihak lain (in privity of contract), dapat menuntut melalui Pasal 1245 KUH Perdata mengenai wanprestasi, sedangkan bagi mereka yang tidak dalam hubungan kontraktual dengan produsen, menggunakan sarana atau Pasal 1365 KUH Perdata mengenai Perbuatan Melawan Hukum. Sedangkan dalam Pasal 1365 KUH Perdata tampak bahwa KUH Perdata menganut prinsip "liabilitybased on fault". Hal ini ditegaskan lagi dalam Pasal 1865 KUH Perdata yang pada dasarnya menyatakan bahwa setiap orang yang mendalilkan bahwa ia mempunyai suatu hak, atau, guna meneguhkan haknya sendiri maupun membantah hak oranglain, menunjuk pada suatu peristiwa, diwajibkan membuktikan adanya hak atau peristiwa tersebut.
Dari prinsip "liability based on fault" ini, konsumen yang dirugikan wajib untuk membuktikan 4 (empat) hal berikut:

1. Kesalahan produsen;

2. Perbuatan produsen sebagai Perbuatan Melawan Hukum;

3. Adanya kerugian;

4. Hubungan kausal antara Perbuatan Melawan Hukum dan kerugian yang diderita.

Prinsip "liability based on fault" tidak sejalan dengan prinsip "strict liability" maupun menurut asas pembuktian terbalik. Berdasarkan pada prinsip “strictliability" pelaku usaha bertanggung jawab langsung terhadap korban dari produknya. Tanggung jawab berdasar prinsip ini tidak hanya terbatas pada adanya kesalahan pada pelaku usaha. Dalam pemberlakuan prinsip ini pelaku usaha tetap harus bertanggung jawab, meskipun ia dapat membuktikan bahwa ia tidak bersalah (berdasarkan prinsip pembuktian terbalik).

Indonesia memiliki sembilan hak konsumen, dua diantaranya yang ada hubungannya dengan masalah sengketa konsumen adalah:

1. Hak untuk mendapatkan advokasi, perlindungan dan upaya penyelesaian sengketa perlindungan konsumen secara patut. 
2. Hak untuk mendapatkan kompensasi, ganti rugi atau penggantian, apabila barang atau jasa yang diterima tidak sesuai dengan perjanjian atau tidak sebagaimana mestinya.

\section{Perlindungan Hak Atas Ganti kerugian}

\section{Bagi Konsumen Kesehatan.}

Setelah Undang-Undang

Perlindungan Konsumen diberlakukan, maka prinsip tanggung jawab yang dianut di dalam Undang-Undang Perlindungan Konsumen adalah prinsip tanggung jawab atas dasar praduga (rebuttablepresumption of liability principle). Hal tersebut dapat dilihat dalam Pasal 19 ayat(1) jo Pasal 28 Undang-Undang Nomor 8 Tahun 1998 tentang Perlindungan Konsumen. Pasal 19 ayat (1) Undang-Undang Perlindungan Konsumen menyatakan Pelaku usaha bertanggung jawab memberikan ganti kerugian atas kerusakan, pencemaran, dan/atau kerugian konsumen akibat mengkonsumsi barang dan/atau jasa yang dihasilkan atau diperdagangkan. UndangUndang Perlindungan Konsumen mengatur lebih luas mengenai subyek yang dapat digugat untuk mengganti kerugian. Konsumen yang dirugikan tidak hanya dapat menggugat secara produsen, tetapi semua yang dinyatakan oleh Undang-Undang Perlindungan Konsumen sebagai pelaku usaha, termasuk di dalamnya adalah dokter yang dianggap sebagai pelaku usaha yang memberikan pelayanan jasa kepada pasien selaku konsumen kesehatan. Selanjutnya, Pasal 28 Undang-Undang Perlindungan Konsumen menyatakan pembuktian terhadap ada tidaknya unsur kesalahan dalam gugatan ganti rugi sebagaimana dimaksud dalam Pasal 19, Pasal 22, dan Pasal 23 merupakan beban dan tanggung jawab pelaku usaha. ( Pasal 19ayat (1) Jo Pasal 28 Undang-Undang Perlindungan Konsumen).

Pelaku usaha akan membayar ganti rugi kepada konsumen yang mengalami kerugian jika ia tidak dapat membuktikan bahwa ia tidak melakukan suatu kesalahan. Namun, konsumen yang dirugikan tidak akan mendapat ganti rugi sedikit pun jika pelaku usaha dapat membuktikan bahwa kerugian yang ditimbulkan bukan merupakan kesalahannya. UU No. 8 tahun 1999 tentang Perlindungan Konsumen, yang memasukkan pelayanan kesehatan sebagai objek hukum perlindungan konsumen, dan menempatkan penerima layanan kesehatan sebagai konsumen serta tenaga kesehatan sebagai pelaku usaha dalam hubungan hukumnya. Dalam Penjelasan Umum UUPK disebutkan bahwa UUPK pada dasarnya bukan merupakan awal dan 
akhir dari hukum yang mengatur tentang perlindungan konsumen, sebab sampai pada terbentuknya UUPK telah ada beberapa UU yang materinya melindungi konsumen, seperti UU No. 23 Tahun 1992 tentang Kesehatan. Dengan demikian UUPK menjadi payung hukum (umbrella act) bagi peraturan perundanganundangan lainnya yang berhubungan dengan konsumen.

Tenaga kesehatan yang dimaksudkan disini adalah setiap orang yang mengabdikan dirinya dalam bidang kesehatan serta memiliki pengetahuan dan atau keterampilan melalui pendidikan di bidang kesehatan. Sesuai ketentuan Pasal 53 ayat (2) Undang-Undang Kesehatan, setiap tenaga kesehatan dalam melakukan tugasnya berkewajiban untuk mematuhi standar profesi dan menghormati hak pasien. Baik standar profesi pada umumnya maupun standar profesi mediknya. Demikian pula dengan penghormatan hak, baik hak-hak pasien pada khususnya, maupun hak-hak konsumen pada umumnya.

Demikian pula, dalam melakukan tugasnya setiap tenaga kesehatan terikat dan tunduk pada norma-norma yang bersifat hukum dan etik. Pelanggaran terhadap hukum dan etika tersebut berkonsekuensi pada pemberian sanksi yang harus dijalankannya. Untuk lebih jelasnya maka dalam Pasal 19 UndangUndang Perlindungan Konsumen diatur secara tegas mengenai tanggung jawab pelaku usaha atas kerugian yang dialami konsumen.

Dokter atau tenaga kesehatan dan rumah sakit dapat dimintakan tanggung jawab hukum, apabila melakukan kelalaian atau kesalahan yang menimbulkan kerugian bagi pasien sebagai konsumen jasa pelayanan kesehatan.

Pasien dapat menggugat tanggung jawab hukum kedokteran (medical liability), dalam hal dokter berbuat kesalahan atau kelalaian. Dokter tidak dapat berlindung dengan dalih perbuatan yang tidak sengaja, sebab kesalahan atau kelalaian dokter yang menimbulkan kerugian terhadap pasien menimbulkan hak bagi pasien untuk menggugat ganti rugi.

Hak pasien adalah mendapatkan ganti rugi apabila pelayanan yang diterima tidak sebagaimana mestinya. Masyarakat sebagai konsumen dapat menyampaikan keluhannya kepada pihak Rumah Sakit sebagai upaya perbaikan intern Rumah Sakit dalam pelayanannya atau kepada lembaga yang memberi perhatian kepada konsumen kesehatan.

Sebagai dasar hukum dari gugatan pasien atau konsumen atau penerimajasa 
pelayanan kesehatan terhadap dokter atau tenaga kesehatan dan Rumah Sakit terdapat dalam Pasal 1365 KUH Perdata. Perlindungan hukum bagi pasien sebagai konsumen jasa pelayanan kesehatan ini mengatur mengenai perbuatan melawan hukum. Oleh karena itu Rumah Sakit berkewajiban untuk memberikan jasa pelayanan kesehatan sesuai dengan ukuran atau standar perawatan kesehatan.

Begitu pula untuk ganti rugi terhadap perbuatan melawan hukum berupa kesengajaan atau kelalaian yang menyebabkan luka atau cacatnya anggota badan, maka ganti rugi diberikan dengan syarat yang sama dengan ganti rugi karena perbuatan melawan hukum yang berupa kesengajaan atau kelalaian yang menyebabkan orang mati sebagaimana di atas. Hanya saja ganti rugi yang dapat dituntut dalam hal menyangkut perbuatan melawan hukum yang berupa kesengajaan atau kelalaian yang menyebabkan luka atau cacatnya anggota badan adalah penggantian biaya penyembuhan dan ganti rugi yang disebabkan oleh luka atau cacat tersebut (Pasal 1371 KUH Perdata). Penilaian terhadap ganti rugi inilah yang biasanya akan dipakai oleh hakim dalam memberikan keputusan menyangkut ganti rugi yang dimintakan oleh pasien selaku konsumen kesehatan apabila terjadi kasus malapraktik.
Lain halnya dengan pemberian ganti rugi menurut Undang-Undang Perlindungan Konsumen sebagaimana yang telah diuraikan di atas bahwa pemberian ganti rugi menurut Pasal 19 ayat (2) Undang-Undang Perlindungan Konsumen. Dalam pasal tersebut konsumen hanya mendapatkan salah satu bentuk penggantian kerugian yaitu ganti kerugian atas harga barang atau hanya berupa perawatan kesehatan, padahal konsumen telah menderita kerugian bukan hanya kerugian atas harga barang tetapi juga kerugian yang timbul dari biaya perawatan kesehatan. Pemberian ganti kerugian juga dalam tenggang waktu 7 (tujuh) hari sejak terjadinya transaksi (Pasal 19 ayat (3) Undang-Undang Nomor 8 Tahun 1999).

\section{Kendala Pemenuhan Hak Atas Ganti} Kerugian Bagi Konsumen Kesehatan

Kata malapraktik tidak ada dalam peraturan perundang-undangan di Indonesia. Pasal 55 ayat (1) UU No 23 Tahun 1992 tentang Kesehatan misalnya, hanya menyebutkan: setiap orang berhak atas ganti rugi akibat kesalahan atau kelalaian yang dilakukan tenaga kesehatan. Sementara pasal 50 UU No 29 Tahun2004 tentang Praktik Kedokteran berbunyi: dokter dan dokter gigi berhak memperoleh perlindungan hukum 
sepanjang melaksanakan tugas sesuai dengan standar profesi atau standar prosedur operasional. Adapun pasal 359360 Kitab Undang Undang Hukum Pidana (KUHP) menyebutkan kelalaian medis yang dianggap tindak pidana hanyalah yang culpa lata atau kelalaian besar. Kelalaian disini berarti harus ada kewajiban yang dilanggar dan harus ada cedera atau kerugian yang disebabkan oleh pelanggaran tersebut. Syarat lainnya, cedera atau kerugian tersebut sudah diketahui dan akibat ketidak hati-hatian yang nyata dimana tidak terdapat faktor pemaaf atau faktor pembenar.

Undang-undang mengenai praktik kedokteran yang dinilai oleh banyak pihak dinilai lebih memihak dokter ketimbang konsumen kesehatan. Undang-undang tersebut justru cenderung melindungi dokter, bukan tenaga medis yang lain, apalagi konsumen kesehatan.

Tak heran jika dalam banyak kasus malapraktik, pasien yang menjadi korbancenderung berada dalam posisi yang lemah.

Jika ada anggota Ikatan Dokter Indonesia (IDI) yang dilaporkan melanggar Kode Etik Kedokteran Indonesia (KODEKI), maka pasien sebagai pihak yang dirugikan dapat melapor kepada IDI setempat. Selanjutnya Majelis Kehormatan Etika Kedokteran
(MKEK) akan bersidang dan menilai apakah anggota tersebut melanggar etika atau tidak. Jika terbukti, maka IDI dapat memberikan sanksi,yang bersifat sanksi moral sampai sanksi pemecatan dari keanggotaan IDI. Namun sayangnya, IDI tidak berwenang mencabut izin praktik yang merupakan kewenangan pemerintah.

Di lain sisi pasien sendiri mengalami kesulitan untuk menuntut dokter secara hukum, sebab tidak ada standar yang membedakan mana tindakan malapraktik, kecelakaan dan kelalaian. Ganti rugi hanya diberikan bila terbukti ada kerugian yang ditanggung pasien. Sedangkan beban pembuktian itu sendiri adapada pasien. "Hukum pidana dan/ atau perdata dapat dilakukan pada dokter hanyabila terjadi kecacatan atau kematian atau reaksi tubuh yang tidak diharapkan akibat dari pelayanan yang tidak sesuai dengan kaidah medis". Malapraktik yang dapat digugat pasien hanya kelalaian medik yang dilakukan dokter atau Rumah Sakit yang menimbulkan kerugian.

Dalam perkembangan hukum kesehatan saat ini muncul juga wacara mediasi penal ${ }^{3}$ sebagai bentuk perlindungan terhadap dokter dan juga

\footnotetext{
${ }^{3}$ SARI, N., HAITI, D., \& IFRANI, I. (2016). Mediasi Penal sebagai Alternatif Penyelesaian Perkara Tindak Pidana Lingkungan Hidup pada Lahan Basah di Provinsi Kalimantan Selatan. Al Adl: Jurnal Hukum, Volume 8 Issue 1, 2016, hlm. 1.
} 
pasien sebagai korban sebagai bentuk win-win solution. ${ }^{4}$

Dalam dua pasal yang mengatur beban pembuktian pidana dan perdata atas kesalahan pelaku usaha dalam UndangUndang tentang Perlindungan Konsumen, yaitu dalam Pasal 22 dan 28, kewajiban pembuktian tersebut dibalikkan menjadi beban dan tanggung jawab dari pelaku usaha sepenuhnya.

Dalam hal yang demikian, selama pelaku usaha tidak dapat membuktikan bahwa kesalahan tersebut bukan merupakan kesalahan yang terletak pada pihaknya,maka demi hukum pelaku usaha bertanggung jawab dan wajib mengganti kerugian yang diderita tersebut.

Dari uraian di atas, dapat dilihat adanya perbedaan beban pembuktian yang diatur dalam Undang-Undang Perlindungan Konsumen dengan pembuktian yang diatur dalam Hukum Acara yang berlaku menurut $\mathrm{KUH}$ Perdata. Berdasarkan ketentuan dalam Pasal 163 HIR dan Pasal 1865 KUH Perdata dapat dikatakan bahwa setiap pihak yang mendalilkan adanya sesuatu hak (dalam hal ini konsumen sebagai

4 Nurhayati, Yati. "The Application Of Balance Idea In settlement of Doctor Malpractice Case Through Penal Mediation"." The 2nd Proceeding "Indonesia Clean of Corruption in 2020" (2017), hlm, 111. pihak yang dirugikan), maka pihak konsumen harus dapat membuktikan bahwa: ${ }^{5}$

a. Konsumen secara aktual telah mengalami kerugian;

b. Konsumen juga harus membuktikan bahwa kerugian tersebut terjadi sebagai akibat dari penggunaan, pemanfaatan, atau pemakaian barang dan/atau jasa tertentu yang tidak layak;

c. Bahwa ketidaklayakan dari penggunaan, pemanfaatan atau pemakaian dari barang dan/atau jasa tersebut merupakan tanggung jawab dari pelaku usaha tertentu;

d. Konsumen tidak "berkontribusi", baik secara langsung atas kerugian yang dideritanya tersebut.

Berdasarkan pada Pasal 19 ayat (3), ganti kerugian akan diberikan kepada konsumen dalam tenggang waktu 7 (tujuh) hari setelah tanggal transaksi, sehingga apabila konsumen yang mengkonsumsi barang di hari kedelapan setelah transaksi tidak akan mendapatkan penggantian kerugian dari pelaku usaha, walaupun secara nyata konsumen yang bersangkutan telah menderita kerugian. Ketentuan ini juga menjadi salah satu

\footnotetext{
${ }^{5}$ Widjaya, Gunawan dan Yani, Ahmad, Hukum Tentang Perlindungan konsumen, Gramedia Pustaka Utama, Jakarta, 2003, hlm. 6869
} 
kendala dalam memberikan ganti kerugian kepada konsumen mengingat dalam dunia kedokteran menyangkut kasus malapraktik, kerugian yang diderita oleh konsumen kesehatan biasanya lebih dari tenggang waktu 7 (tujuh) hari sebagaimana yang tercantum dalam ketentuan Pasal 19 ayat (3) UndangUndang Perlindungan Konsumen. Oleh karena itu, hal tersebut juga yang menyebabkan hakim lebih condong untuk menyelesaikan kasus malapraktik yang terjadi dengan menggunakan ketentuanketentuan sebagaimana dalam KUH Perdata dan bukan menggunakan UndangUndang Nomor 8 Tahun 1999 Tentang Perlindungan Konsumen. Padahal dapat dilihat bahwa dalam Undang-Undang Perlindungan Konsumen terdapat ketentuan yang memberikan kemudahan bagi konsumen untuk mendapatkan ganti kerugian yaitu menyangkut asas pembuktian yang dianut dalam undangundang tersebut menggunakan asas pembuktian terbalik, sehingga pihak pelaku usaha yang harus dapat membuktikan bahwa pelaku usaha yang bersangkutan tidak melakukan perbuatan melawan hukum yang menyebabkan kerugian yang diderita oleh konsumen. Hal ini berbeda dengan ketentuan pembuktian dalam Hukum Acara Perdata yang mana tetap berlaku asas bahwa barangsiapa yang mendalilkan mempunyai suatu hak maka ia harus membuktikan akan haknya itu, sehingga di sini konsumen yang harus membuktikan kesalahan pada pelaku usaha.

Selain itu, kendala yang lain yaitu mengenai sulitnya untuk mendapatkan Rekam Medik (RM) yang apabila dikaitkan dengan ketentuan Pasal 164 HIR/Pasal 1866 KUH Perdata dapat menjadi alat bukti surat. Padahal dengan Rekam Medis ini maka dapat membantu dalam proses pembuktian di persidangan sehingga akan lebih memudahkan pasien selaku konsumen kesehatan untuk mendapatkan ganti rugi atas kasus malapraktik yang telah terjadi.

\section{PENUTUP}

Konsumen kesehatan disini adalah pasien kesehatan yang mengalami malapraktik medik serta belum mendapat perlindungan hukum atas hak ganti rugi sebagaimana yang diharapkan. Pemenuhan atas hak ganti rugi bagi konsumen kesehatan hanya didasarkan pada ketentuan dalam Pasal 1365 KUH Perdata tentang Perbuatan Melawan Hukum yang mana konsumen kesehatan harus berupaya untuk bisa membuktikan kesalahan yang telah dilakukan oleh 
pelaku usaha jasa layanan kesehatan (dokter dan Rumah Sakit).

Pemenuhan hak atas ganti kerugian bagi konsumen kesehatan dalam halterjadi malapraktik medik seringkali mengalami kendala yang cukup berarti. Hal ini disebabkan belum adanya ketentuan yang secara jelas mengatur mengenai malapraktik medik dan memberikan perbedaan yang jelas dengan kelalaian atau kekurang hati-hatian. Oleh karena itu, dalam memutus kasus malapraktik menggunakan ketentuan dalam KUH Perdata khususnya Pasal 1365 KUH Perdata.

\section{DAFTAR PUSTAKA}

\section{Buku}

Maryati, Ninik, Malpraktik Kedokteran, 1988, Bina Aksara Jakarta

Miru, Ahmad dan Yodo, Sutarman,Hukum Perlindungan Konsumen, 2004, Rajagrafindo Indonesia, Jakarta

Widjaya, Gunawan dan Yani, Ahmad, Hukum Tentang Perlindungan konsumen, 2003, Gramedia Pustaka Utama, Jakarta

\section{Jurnal}

Sari N., Haiti, D., \& Ifrani, I. (2016). Mediasi Penal sebagai Alternatif Penyelesaian Perkara Tindak Pidana Lingkungan Hidup pada Lahan Basah di Provinsi
Kalimantan Selatan. Al Adl: Jurnal Hukum, 8(1).

Nurhayati, Yati. "The Application Of Balance Idea In settlement of Doctor Malpractice Case Through Penal Mediation"." The 2nd Proceeding "Indonesia Clean of Corruption in 2020" (2017).

\section{Perundang-undangan}

Undang-Undang Republik Indonesia Nomor 36 Tahun 2009 Tentang Kesehatan.

Undang-undang Republik Indonesia Nomor 8 Tahun 1999 tentang Perlindungan Konsumen.

Undang-Undang Republik Indonesia Nomor 29 tahun 2004 tentang Praktik Kedokteran.

Peraturan Menteri Kesehatan Republik Indonesia Nomor. 585/MEN.KES/Per/IV/1989. 
